\title{
JOURNEYS, FRONTIERS AND MEDICAL EDUCATION
}

\author{
Roseby $R$ \\ Adjunct Clinical Associate Professor \\ Department of Paediatrics, Monash University \\ Respiratory and General Paediatrician \\ Head of Medical Specialties and Head of Postgraduate Medical Education \\ Monash Children's Hospital \\ Melbourne, Australia \\ ORCID: https://orcid.org/0000-0001-5005-6772
}

\section{Citation}

Roseby R. Journeys, Frontiers and Medical Education. BJHS 2019, 4(1)8: 580-581

DOI: http://dx.doi.org/10.3126/bjhs.v4i1.23924

Nepal is a country of beautiful people and beautiful scenery. Nepali people are rightly proud of the Himalayas of which they are custodians, with eight of the world's ten highest mountains sited in Nepal in whole or in part. Mount Everest and other mountains in Nepal are magnets for travelers seeking adventure and the feeling of achieving something they previously thought not possible. With more than half a million international visitors to Nepal per year, tourism is an important contributor to the country's economy.

Not all visitors to Nepal leave. In the 1980s the risk of death among those trekking in Nepal was 15:100,000 trekking permits, and over the 86 years from 1921-2006 for those climbing above Mt Everest base camp the rate of death was $1.3 \%{ }^{1,2}$ That we know these figures with confidence speaks to the quality of Nepal's record keeping infrastructure around health care and expeditioning. Nepal has well-established infrastructure for rescue and medical care. Other journeys in Nepal can be hazardous. Nepal has a high rate of road traffic injury, a problem shared by other low to middle income countries particularly in Asia. ${ }^{3}$ Recently, a survey of nearly 9000 Nepali households showed $2 \%$ were affected by injury from road trauma, and a Dharan survey of 1388 households containing 7063 people found a road injury rate of around $0.5 \%{ }^{4,5}$ Pedestrians and motor bike riders appear especially vulnerable. ${ }^{6}$ Journeys can be hazardous but travel is a necessary aspect of life for most.

All of us in medicine are on a journey of medical education. The journey begins formally in medical school, with graduation marking a transition to supervised medical practice and learning on-the-job. With increasing experience, specialization and seniority there are further transitions in learning method, with an increasing need for self-direction. Education opportunities are not only conferences, meetings and other formal events of course. We learn from discussing cases with peers, handover ward rounds, multidisciplinary case meetings, and from our trainees who bring new ideas and enthusiasm to the conversation. We learn from patients, particularly when they have a problem or question which challenges our thinking. Our patients, peers and clinical supervisors are our best teachers. The use of social media tools such as Twitter has seen the development of FOAMED (free open access medical education) and rapid dissemination of information and timely access to expert opinion. Infrastructure enabling us to track and reflect on our learning journey through medical education is highly valuable, just like the infrastructure which tracks other journeys in Nepal to facilitate evidence-based decisions.

So what is the next frontier in medical education? Simulation as a modality of medical education is moving from an optional add-on to an essential complement to other education tools. The first wave of expensive, high tech, highly realistic manikins now coexists with low tech, low cost and in-situ simulation regardless of a country's GDP. Concentration on communication skills, team dynamics and processes can result in significant skill acquisition and improved quality of care and both outcomes are difficult to achieve or demonstrate in traditional education modalities. ${ }^{7,8}$ The keys to the use of simulation for education are appropriately trained and experienced facilitators and clarity of learning objectives and group outcomes, and measuring whether or not these are achieved. As much as we all might want to play with high tech toys, they are far less important. As individuals, centers and health systems it is useful to reflect on where we are on our medical education journey. 


\section{REFERENCES}

1. Shlim DR, Houston R. Helicopter Rescues and Deaths Among Trekkers in Nepal. JAMA. 1989;261(7):1017-9.

2. Firth PG, Zheng $\mathrm{H}$, Windsor JS, Sutherland Al, Imray CH, Moore GWK, et al. Mortality on Mount Everest, 1921-2006: descriptive study. BMJ. 2008;337:a2654.

3. Karkee R, Lee AH. Epidemiology of road traffic injuries in Nepal, 20012013: systematic review and secondary data analysis. BMJ Open. 2016;6(4):e010757.

4. Alam K, Mahal A. The Economic Burden of Road Traffic Injuries on Households in South Asia. PLoS ONE [Electronic Resource] 2016;11(10):e0164362.

5. Ghimire A, Nagesh S, Jha N, Niraula SR, Devkota S. The burden of injury in terms of economics loss and disability days: a community based study form eastern Nepal. Kathmandu University Medical Journal. 2011;9(34):27-30.
6. Huang L, Adhikary KP, Choulagai BP, Wang N, Poudyal AK, Onta SR. Road Traffic Accident and its Characteristics in Kathmandu Valley. Journal of the Nepal Medical Association. 2016;55(203):1-6.

7. Gorantla S, Bansal U, Singh JV, Dwivedi AD, Malhotra A, Kumar A Introduction of an undergraduate interprofessional simulation based skills training program in obstetrics and gynaecology in India. Advances in Simulation. 2019;4(1):6.

8. Theilen $U$, Fraser L, Jones $P$, Leonard P, Simpson D. Regular in-situ simulation training of paediatric Medical Emergency Team leads to sustained improvements in hospital response to deteriorating patients, improved outcomes in intensive care and financial savings. Resuscitation. 2017;115:61-7. 